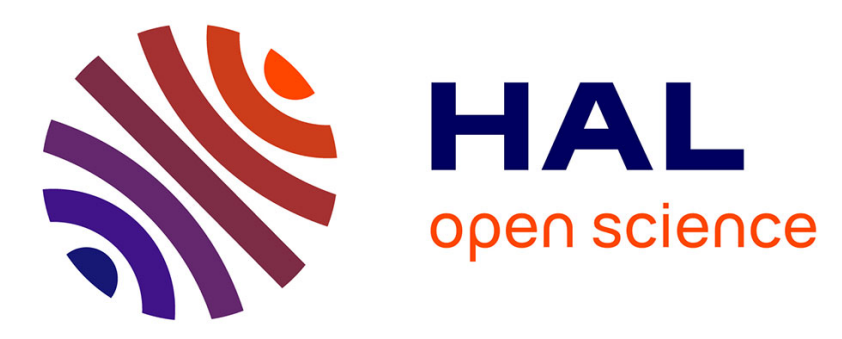

\title{
Toward an accelerated biodeterioration test to understand the behavior of Portland and calcium aluminate cementitious materials in sewer networks
}

Jean Herisson, Eric D. van Hullebusch, Marina Moletta-Denat, Pascal Taquet, Thierry Chaussadent

\section{To cite this version:}

Jean Herisson, Eric D. van Hullebusch, Marina Moletta-Denat, Pascal Taquet, Thierry Chaussadent. Toward an accelerated biodeterioration test to understand the behavior of Portland and calcium aluminate cementitious materials in sewer networks. International Biodeterioration and Biodegradation, 2013, 84, pp 236-243. hal-00877540

\author{
HAL Id: hal-00877540 \\ https://hal.science/hal-00877540
}

Submitted on 28 Oct 2013

HAL is a multi-disciplinary open access archive for the deposit and dissemination of scientific research documents, whether they are published or not. The documents may come from teaching and research institutions in France or abroad, or from public or private research centers.
L'archive ouverte pluridisciplinaire HAL, est destinée au dépôt et à la diffusion de documents scientifiques de niveau recherche, publiés ou non, émanant des établissements d'enseignement et de recherche français ou étrangers, des laboratoires publics ou privés. 


\title{
Toward an accelerated biodeterioration test to understand the behavior of Portland and calcium aluminate cementitious materials in sewer networks
}

\author{
Jean Herisson $^{\mathrm{a}}$, Eric D. van Hullebusch ${ }^{\mathrm{b}}$, Marina Moletta-Denat ${ }^{\mathrm{c}}$, Pascal Taquet ${ }^{\mathrm{d}}$, Thierry $^{2}$
}

Chaussadent $^{\mathrm{a}}$

\author{
a: Université Paris-Est, Institut Français des Sciences et Technologies des Transports, de l'Aménagement et des \\ Réseaux (IFSTTAR), 58 boulevard Lefebvre, 75732 Paris Cedex 15, France. \\ b: Université Paris-Est, Laboratoire Géomatériaux et Environnement (LGE), EA4508, 5 boulevard Descartes, \\ 77454 Marne-la-Vallée Cedex 2, France. \\ c: Centre Scientifique et Technique du Bâtiment (CSTB), 84 avenue Jean Jaurès, Champs-sur-Marne, 77447 \\ Marne-la-Vallée Cedex 2, France. \\ d: Kerneos Research and Technology Center, 1 rue Le Chatelier, ZAC Parc Technologique, 38090 Vaulx- \\ Milieu, France. \\ Contact: jean.herisson@ifsttar.fr, Eric.vanHullebusch@univ-paris-est.fr, marina.moletta@cstb.fr, \\ pascal.taquet@kerneos.com, thierry.chaussadent@ifsttar.fr
}

\begin{abstract}
Sewer networks contain many aggressive and corrosive agents for pipe materials. One type of damage can be ascribed to concrete corrosion by biogenic sulfuric acid. According to field data, cementitious materials have different behaviors depending in particular on cement type: Those made with calcium aluminate cement (CAC) offer better performance than those made of ordinary Portland cement (OPC). The development of an accelerated and accurate laboratory test is essential to better understand the mechanisms involved for all cementitious materials. However, to define such a test, some additional knowledge is required. The present study deals with in situ experiments in order to determine the biochemical parameters
\end{abstract}


influencing the behaviors of OPC and CAC materials. Based on these determinations, supplemented by laboratory studies, it can be concluded that abiotic oxidation of hydrogen sulfide, bioreceptivity of the mineral surface, and growth of bacterial strains depend greatly on cementitious material types. All these results, complemented by literature data, lead to consideration of what the best parameters are to study biodeterioration of cementitious materials, and have been helpful in designing the biodeterioration chamber tested.

Keywords:

Biodeterioration

Cementitious materials

Sewer network

$\mathrm{H}_{2} \mathrm{~S}$

Calcium aluminate cement

Portland cement 


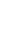

\section{Introduction}

In most industrialized countries, sewer systems are more than 40 to 50 years old and now require major rehabilitation. From another perspective, in 1991 the Council of the European Union adopted a directive on the need to treat urban wastewater properly. Compliance with these regulations has always led and will probably always lead, to an increase in the construction of sewerage and wastewater treatment plants. More recently, the United Nations General Assembly declared 2008 as an International Year of Sanitation with the objective of halving the number of people without access to safe water and adequate sanitation by 2015 .

Thus, the need to rehabilitate parts of the sewer network in large cities and to construct new networks arising from EU directives and United Nations wishes now leads managers and manufacturers to consider the best ways to build sustainable sanitation facilities and to optimize sanitation management protocols.

Among the areas needing improvement, the degradation of materials, and particularly biodeterioration of cementitious materials, appears fundamental. This is an extremely dangerous and damaging phenomenon to sewer network structures, which was studied for the first time by Olmstead and Hamlin (1900), who described the deterioration of bricks in the sewer network of Los Angeles. Jointed mortar between the bricks disintegrated and ironwork was heavily rusted. These authors also stated that the mortar joint had ballooned to two to three times its original volume, leading to the destruction or the loosening of some bricks.

This type of damage can be ascribed to cementitious material corrosion by biogenic sulfuric acid and represents $9 \%$ of the damage described in sewer networks (Kaempfer and Berndt, 1999). Phenomena involved are depicted in Fig. 1. Relatively thick layers of sedimentary sludge and sand accumulate at the bottom of the pipes, which leads to the 
establishment of anoxic areas (typically $1 \mathrm{~mm}$ thick). Under these anaerobic conditions, sulfate-reducing bacteria (SRB) can grow using oxidized sulfur compounds present in the effluent as electron acceptor and excrete hydrogen sulfide $\left(\mathrm{H}_{2} \mathrm{~S}\right)$. Hydrogen sulfide degassed in the aerial part of the pipe can impact the cementitious materials in two ways: either directly by reacting with the cementitious materials and leading to a decrease in $\mathrm{pH}$, or indirectly through its use as a nutrient by sulfur-oxidizing bacteria (SOB), which produce sulfuric acid (Islander et al., 1991; Roberts et al., 2002; Okabe et al., 2007). The cement matrix is then dissolved by sulfuric acid and, depending on its composition, formation of expansive secondary mineral products such as gypsum and ettringite is possible.

The present study focuses only on the second stage of the global process (i.e., the biodeterioration of cementitious materials in the presence of $\mathrm{H}_{2} \mathrm{~S}$ ), which can be broken down into four steps, as shown in Fig. 1: abiotic oxidation of $\mathrm{H}_{2} \mathrm{~S}$ into elemental sulfur onto the surface of cementitious material; oxidation of sulfur-containing molecules to sulfuric acid by bacteria; diffusion of sulfuric acid into the degradation product layer; and acid attack on healthy cementitious materials.

According to previous on-site experiments (Goyns, 2001, 2003; LCA 1; LCA 2) cementitious materials made with calcium aluminate cement (CAC) perform better than those made with ordinary Portland cement (OPC).

Most of the data published are based only on OPC studies. By contrast, the good behavior of CAC in sewer networks is poorly documented. Therefore, it appears necessary to better understand the deterioration mechanisms associated with CAC and OPC materials by defining an accelerated test relevant to these materials, as well as to any other materials that can be used in sewer networks.

Many studies have already been performed with different accelerated tests aimed at mimicking the bio-physicochemical conditions encountered in sewer networks. Some of them 
(Monteny et al., 2000; Roy et al., 2001; De Belie et al., 2004) simply proposed chemical tests as the phenomenon can be considered at its last step as an acid attack. The basis of these tests is the immersion of concrete samples into a sulfuric acid solution for about one month, after which the sample's weight loss is measured. Some of the proposed tests are complemented by a step of sample surface brushing in order to mimic the tidal area effect in the pipe and therefore to create the worst possible conditions. In general, the results obtained by these chemical tests are not in agreement with in situ experimental results.

Some other studies deal with biochemical accelerated tests by introducing microorganisms, in order to more closely simulate reality. A Heidelberg University (Germany) group (Hormann et al., 1997; Schmidt et al., 1997) worked on the design of a simulation chamber using only one bacterial strain (Acidithiobacillus thiooxidans). Mortar samples were placed in a reactor and for $5 \mathrm{~min} \mathrm{~h}^{-1}$ they were immersed in the culture media. This test has two major disadvantages: Being immersed in a culture medium at $\mathrm{pH} 3.5$ leads to a chemical test rather than a biological one, and the washing of the sample each hour modifies the sample surface conditions.

A University of Ghent (Belgium) team (Vincke et al., 1999; De Belie et al., 2004) has developed a test that recreates the worst conditions encountered in sewer networks. Samples of mortars were exposed to cycles of deterioration: 3 days of exposure to $250 \mathrm{ppm} \mathrm{of} \mathrm{H}_{2} \mathrm{~S}, 10$ days of immersion in the culture medium of $A$. thiooxidans, 2 days of washing by water, and finally 2 days of drying. This test is far from realistic conditions and some of the steps are not justified considering in situ conditions. Moreover, with this test, biodeterioration of samples is also disturbed by chemical reactions at the sample surface.

The University of Hamburg (Germany) has developed a biodeterioration chamber that allows recreating the conditions met in sewer systems (Milde et al., 1983; Sand et al., 1992, 1994; Ehrich et al., 1999). For this purpose, a wide chamber $\left(1 \mathrm{~m}^{3}\right)$ with air circulation (250 
$\mathrm{m}^{3} \mathrm{~h}^{-1}$ ) and controlled relative humidity (close to $98 \%$ ) and temperature (approximately $30^{\circ} \mathrm{C}$ ) is used. The mortar samples are sprayed with a solution of mineral salts essential for the growth of 12 bacterial strains isolated from the sewer network of Hamburg. The atmosphere in this chamber contains between 15 and 20 ppm of $\mathrm{H}_{2} \mathrm{~S}$. This accelerated test appears to represent in situ mechanisms and displays an acceleration factor of 24 compared to on-site conditions (Sand et al., 1992; Ehrich et al., 1999).

This present paper focuses on both in situ and laboratory studies carried out on mortar samples, with the objective of providing useful knowledge concerning the effect of biodeterioration on Portland and calcium aluminate cements. Moreover, these new data are analyzed in order to improve the accelerated biodeterioration tests currently examined.

\section{Materials and methods}

\subsection{Samples}

Mortars were cast with OPC or CAC. Their chemical oxide compositions are given in Table 1. For all samples, the water-to-cement and siliceous-sand-to-cement ratios are, respectively, 0.37 and 1.44 .

For laboratory studies, samples were cast in $2 \times 2 \times 16 \mathrm{~cm}^{3}$ moulds. After one-day hydration, they were sawn in order to obtain seven samples of $2 \times 2 \times 2 \mathrm{~cm}^{3}$. Each of them has three molded faces and two sawed faces. For in situ experiments, cylindrical samples $(6 \mathrm{~cm}$ diameter, $14 \mathrm{~cm}$ high) were prepared with a PVC tube anchor for their suspension in a sewer network. The two types of sample are shown in Fig. 2. All the samples were kept in plastic bags until studies in order to avoid desiccation. 


\subsection{In situ experiments}

Cylindrical mortar samples were exposed in two sewer networks. The first one (Site 1) has a low biodeterioration potential with an $\mathrm{H}_{2} \mathrm{~S}$ concentration between 0 and $20 \mathrm{ppm}$ and a temperature between 18 and $25^{\circ} \mathrm{C}$. Site 2 is much more aggressive, with an $\mathrm{H}_{2} \mathrm{~S}$ concentration ranging from 100 to $200 \mathrm{ppm}$ and a temperature ranging from 25 to $30^{\circ} \mathrm{C}$.

For each site, samples are suspended in a PVC box located in the headspace of the sewer network. There are three replicates of each kind of mortar sample.

For each sampling (i.e., every 4 months), different parameters are monitored: visual changes, weight, and surface $\mathrm{pH}$. Moreover, one of the three cylindrical samples is used to study biofilm microbial diversity using molecular techniques. Samples are scraped with a brush impregnated with a guanidine thiocyanate solution ( $\mathrm{pH} 7.5)$ to extract and preserve total DNA from biofilms. DNA samples are held in the guanidine thiocyanate solution at $-80^{\circ} \mathrm{C}$ for transport and storage until analyzed. DNA is extracted using an MP Biomedical kit, the Fast DNA $^{\circledR}$ SPIN Kit for Soil, which allows extraction and cleansing of the genetic material from a sample with an environmental background (e.g., ground, faeces, wastewater, sludge). This kit provides the advantage of quick isolation (less than $30 \mathrm{~min}$ ) of the genomic DNA for use in PCR (polymerase chain reaction). The DNA extracted is amplified by PCR and used for CESSCP analysis (Capillary Electrophoresis Single-Strand Conformation Polymorphism). This molecular fingerprint tool allows for the study of microbial diversity present in environmental ecosystems. One microliter of total extracted DNA is used per PCR-SSCP amplification. The w104 (6-FAM labelled) and w49 (Godon et al., 1997) are used for the V3 region of 16S ribosomal DNA. The PCR-SSCP amplification mix contains 1.25 units of Pfu Turbo (Stratagene, La Jolla, CA), $5 \mu \mathrm{l}$ of $10 \times$ buffer, $200 \mu \mathrm{M}$ of dNTPs (tri-phosphate desoxyribonucleotides), and $200 \mathrm{ng}$ of each primer, with water added to a final volume of 50 
$\mu$ l. The thermal profile used for amplification of ribosomal RNA genes is as follows: incubation at $94^{\circ} \mathrm{C}$ for $2 \mathrm{~min}$, and then 25 cycles of denaturation at $94^{\circ} \mathrm{C}$ for $30 \mathrm{~s}, 61^{\circ} \mathrm{C}$ for 30 $\mathrm{s}$, and $72^{\circ} \mathrm{C}$ for $30 \mathrm{~s}$. The CE-SSCP analysis is carried out with ABI 3130 (Applied Biosystems) as described by Delbes et al. (2000, 2001). recovered in order to measure $\mathrm{pH}$ and ATP content. This latter parameter is determined by an ATPmeter type Novalum ${ }^{\circledR}$ from Charm Science using WaterGiene ${ }^{\circledR}$ swabs. These swabs, initially made for use in the food industry, are quantitative, give repeatable results, and are easy to use.

\subsection{Laboratory experiments}

Considering two of the four biodeterioration steps (see Fig. 1), tests were carried out to determine the influence mortar sample type had on the results and to propose a way to take into account this influence in an accelerated test.

\subsubsection{Sulfuric acid impact}

Cubic samples were immersed in sulfuric acid solutions ( $\mathrm{pH} 1$ and 2) for a week, as proposed by Espinosa et al. (1996). Twice a day, a part of the solution was sampled for elemental analysis and solid samples were weighed. Chemical analyses were made by ICPOES with an ULTIMA 2000 Jobin-Yvon.

\subsubsection{Abiotic oxidation of $\mathrm{H}_{2} \mathrm{~S}$}

Samples of mortar were exposed to $20 \mathrm{ppm}$ of $\mathrm{H}_{2} \mathrm{~S}$ for three months. Each month, a sample was removed to be analyzed by environmental scanning electron microscopy (ESEM). 
Observations were made with an ESEM type Quanta 400 from FEI. Chemical analyses were made using an energy dispersive X-ray spectroscopy system, EDAX DX 4i, from Oxford Instruments.

\section{Results and discussion}

\subsection{Field experiments}

The first step to get a better understanding of the mechanisms involved in cementitious materials' biodeterioration is to determine the consequences of in situ exposure on samples of such materials.

After four months in sewer networks, the two sites affected the samples differently. As expected, site 1 was less damaging than site 2. Upon opening the manhole giving access to the exposure boxes, a preliminary observation on the exterior of the boxes was made. The samples exposed on site 1 kept their original appearance, while the box suspended in site 2 had a clear yellow-white color with the presence of significant deposits on the top of the box (Fig. 3).

Figure 4 presents the visual appearance of the mortar samples. For site 1, one can notice little change on samples compared to the controls. A thin coat of whitish color containing glittering crystals was observed on the surface of all samples. This layer is barely visible in the Fig. 4 photos. The OPC samples of this site are slightly darkened locally while CAC samples displayed a slightly bluish tint.

Site 2 samples displayed more advanced deterioration. Most of the samples had changed color and phenomena associated with bursting were observed on the upper face. The OPC samples became totally black and a relatively thick deposit (around $5 \mathrm{~mm}$ ) formed at the 
retention zones (at the top of the test tubes or in the macro-porosity of the samples). The top also had burst under the formation of expansive mineral phases. The CAC samples hung in this site became partially black with white deposits covering the surface of the samples.

One of three samples of each formulation was brushed to remove the deterioration products that had formed. This test aimed to represent a tidal zone with the loss of the deterioration products occurring during every rise in the water level. While samples exposed on site 1 did not present real alteration, samples brushed from site 2 showed a significant loss of weight. Mass loss of OPC samples (1.59\%) was four times higher than those of CAC $(0.35 \%)$ on site 2 .

The $\mathrm{pH}$ of all samples was also measured on four sample faces: top face, one on the bottom face, and two on the sides (Fig. 5). It can be observed that there was a $\mathrm{pH}$ increase from the top face to the bottom face.

The sampling of sub-aerial biofilm growing on cementitious material surfaces allowed extraction and quantification of the total DNA. It can be seen that the OPC samples (total DNA extracted after four months: $10 \mathrm{ng} \mathrm{cm}^{-2}$ for site 1 and $155 \mathrm{ng} \mathrm{cm}^{-2}$ for site 2) are more bioreceptive than the CAC ones (total DNA extracted after four months: $4 \mathrm{ng} \mathrm{cm}^{-2}$ for site 1 and $48 \mathrm{ng} \mathrm{cm}^{-2}$ for site 2). Both exposure sites favor bacterial development, but samples from site 2 display up to 15 times more biomass than samples from site 1 .

CE-SSCP analysis performed of the bacterial extracted DNA reveals that the cement composition has a major role in the establishment of the biofilm, considering that the microbial diversity decreases from OPC to CAC (data not shown). In addition, site location has a strong impact: Samples from site 1 present a lower microbial diversity compared to those from site 2 .

The analysis of condensed water in the PVC tube anchor showed that pHs are always close to 1 . By contrast, ATP concentrations from OPC samples $\left(1.1 \times 10^{8}\right.$ relative light units $)$ 
are much higher than those from CAC samples $\left(3.8 \times 10^{4} \mathrm{RLU}\right)$, indicating greater microbial activity. All results (mass loss, DNA quantity, and microbial activity) indicate that CAC seemed to inhibit bacterial strains, their activity, and, as a consequence, the degradation of cementitious materials.

Moreover, the in situ experiments showed that the environmental conditions significantly influenced the biodeterioration of cementitious materials, as shown by the concentration of $\mathrm{H}_{2} \mathrm{~S}$ and temperature.

Several hypotheses can be made based on in situ experiments. The main element of CAC materials, aluminum, may have a major role in the good behavior of these materials by acting like an inhibitor for microorganisms involved in the biodeterioration process. The surface state may also influence a part of the phenomenon, considering that hydrates present in the two materials are quite different. To answer these questions, additional laboratory experiments are required. Such experiments should aim to design an accelerated test reproducing the bio-physicochemical processes occurring in sewer networks.

\subsection{Study of biodeterioration mechanisms}

materials in sewer systems occur via a sulfuric acid attack. Sulfuric acid interacts with some of the chemical compounds of the cementitious material, thereby forming characteristic phases (Okabe et al., 2007), such as gypsum or ettringite. Despite the fact that chemical experiments are not suitable for the classification of cementitious materials in terms of durability in sewer networks, it is interesting to carry out these tests in order to observe ions, especially aluminum, leached into solution. 
For that purpose, we plunged cubes of mortar $2 \mathrm{~cm}$ per side into solutions of sulfuric acid at $\mathrm{pH} 1$ or 2, for one week (Fig. 6).

Chemical analyses were performed on the acidic solution to monitor the leaching of ions in solution every $24 \mathrm{~h}$. Figure 7 indicates that whatever the mortar type, calcium concentration reaches values of the order of $10 \mathrm{mg} \mathrm{cm}^{-2}$, but the behavior of the aluminum differs depending on the type of mortar. It dissolves sparsely in solution in the case of OPC and reaches values of $10 \mathrm{mg} \mathrm{cm}^{-2}$ for CAC. Aluminum is known to have bacteriostatic properties (Karlik et al., 1980; Munns et al., 1981; Wood et al., 1988; Exley and Birchall, 1992) so it is possible that that is one explanation for the good behavior of CAC materials in the in situ experiments.

Monitoring of the sample mass was also performed and the results are reported in Fig. 8. The CAC lost up to twice the weight that Portland cement did during an acid attack by immersion at $\mathrm{pH} 1$. Similar trends were observed at $\mathrm{pH} 2$.

As reported by previous studies (Monteny et al., 2000; De Belie et al., 2004; O'Connell et al., 2010; Magniont et al., 2011), an accelerated biodeterioration test cannot rely on a simple immersion test in an acidic solution. For evidence, in situ experiments indicate that cementitious materials made with CAC are less deteriorated than those with OPC, but with chemical tests, CAC materials are more deteriorated than OPC. Furthermore, surface $\mathrm{pH}$ of the CAC materials for in situ experiments never decreases below 3.5 - 4. This limit corresponds to the stability of the alumina (Lamberet et al., 2008). Using a pH lower than 4 for the acid attack is not representative of conditions met by CAC materials.

Thus for the accelerated biodeterioration experiment, it is necessary to involve microorganisms to recreate the real decrease of $\mathrm{pH}$.

According to the literature, biodeterioration mechanisms of cementitious materials in sewer networks also bring in a succession of microorganisms clearly identified in the case of 
OPC (Islander et al., 1991; Okabe et al., 2007). It is thus necessary to recreate this bacterial succession in the laboratory to be able to gradually lower the $\mathrm{pH}$ of the surface of the mortar samples.

The first stage of biodeterioration of cementitious materials in sewer systems is the transformation of hydrogen sulfide into elemental sulfur on the surface of the materials. It seems that the oxidation of hydrogen sulfide in sewer networks can follow two paths (Parker, 1947) depending on the state of degradation of cementitious materials. On healthy materials, sulfides can be oxidized chemically and produce thiosulfate $\left(\mathrm{S}_{2} \mathrm{O}_{3}{ }^{2-}\right)$ or tetrathionate $\left(\mathrm{S}_{4} \mathrm{O}_{6}{ }^{2-}\right)$. In contrast, on deteriorated concrete with a lower $\mathrm{pH}$, sulfide can be oxidized into elemental sulfur. However, transformation of sulfides can also involve microorganisms. Suzuki (1999) states that $\mathrm{H}_{2} \mathrm{~S}$ can be transformed by sulfur-oxidizing microorganisms following some other mechanisms. Therefore, it appears that the oxidation of $\mathrm{H}_{2} \mathrm{~S}$ is not well understood and that our knowledge about the mechanisms involved needs to be expanded.

To study the significance of this step, $20 \mathrm{ppm}$ of gaseous $\mathrm{H}_{2} \mathrm{~S}$ was maintained in contact with mortar samples for three months. Examination performed with SEM (Fig. 9) revealed a heterogeneous and diffuse sulfur deposit on the surface of OPC materials, while CAC materials did not display this.

Deposits of sulfur in the case of OPC materials seem to be favored in the periphery of aggregates. In fact, this corresponds to a transition zone rich in calcium for OPC materials. It can be concluded that the transformation of $\mathrm{H}_{2} \mathrm{~S}$ into elemental sulfur requires the intervention of a catalyst in the form of cations, such as calcium for this study, but also of metallic cations (Fe, $\mathrm{Cu}, \mathrm{Zn}$, etc.) for other studies (U.S. EPA, 1992; Nielson et al., 2005; Firer et al., 2008).

The difference of deposition of elemental sulfur on the surface of mortar samples for OPC and CAC could be an additional reason for the good behavior of CAC in the face of 
275 biodeterioration features of sewer systems. Furthermore, it indicates that $\mathrm{H}_{2} \mathrm{~S}$ gas has a major

276 role in the processes of biodeterioration because it has different oxidation/deposition behavior

277 according to materials composition. Thus it is necessary to have $\mathrm{H}_{2} \mathrm{~S}$ for a suitable accelerated 278 biodeterioration experiment.

\subsection{Development of an accelerated experiment}

To create a simple, effective, and reproducible accelerated test, it is important to have

a completely homogeneous air volume with the environment controlled for temperature, relative humidity, and concentration of $\mathrm{H}_{2} \mathrm{~S}$. Considering these parameters, a biodeterioration chamber of a cubic meter, homogenized by a powerful ventilating system, was chosen. The relative humidity was purposely maintained at a very high level to allow water condensation at $30^{\circ} \mathrm{C}$. This temperature was chosen because it corresponds to the optimal growth temperature of the selected bacteria. The $\mathrm{H}_{2} \mathrm{~S}$ is continuously injected at $20 \mathrm{ppm}$.

According to Parker (1947), Islander et al. (1991), Robert et al. (2002), and Okabe et al. (2007), only a few bacterial strains are involved in biodeterioration of cementitious materials by oxidizing sulfur-containing molecules. The growth patterns of these bacteria are different depending on environmental conditions, and there is a succession of bacteria for colonization that is determined by the material surface $\mathrm{pH}$ (Islander et al., 1991; Lamberet et al., 2008). The selected bacterial strains for the present study were Halothiobacillus neapolitanus, Starkeya novella, Thiomonas intermedia, and Acidithiobacillus thiooxidans. The first three are neutrophilic and the last is acidophilic. 
- Surface material pH, which is a crucial parameter as shown by Islander et al. (1991) and Roberts et al. (2002), since it allows to highlights progress of the process.

- X-ray diffraction and thermal analysis (DTA-TG), in order to understand the transformation of materials during the degradation.

- Biochemical analysis aimed at determining the number of microbial cells growing on the surface. This analysis is correlated to ATP activity measurement and microbial protein content determination.

This biodeterioration chamber is expected to enable accelerated testing similar to the biodeterioration chamber designed by the Hamburg University research team (Milde et al., 1983; Sand et al., 1992, 1994; Ehrich et al., 1999). However, in contrast with Ehrich et al. (1999), four bacterial strains purchased from DSMZ collection were introduced into the chamber. The use of referenced bacterial strains allows this test to be replicated anywhere in the world the laboratory is located.

Currently the biodeterioration chamber is being tested with different mortar samples and preliminary results are promising.

\section{Conclusions}

On-site experiments provide important data relevant to a better understanding of biodeterioration of cementitious materials. In fact, it has been found that CAC materials perform better than those with OPC, and the biomass that develops on the surface of the former is different and less abundant. The good behavior of CAC materials could be due to their high aluminum content, which could inhibit the growth of microorganisms. 

addition of sulfuric acid) do not allow estimation of the service life of materials in sewer systems. The work performed with $\mathrm{H}_{2} \mathrm{~S}$ showed that the presence of $\mathrm{H}_{2} \mathrm{~S}$ was required when one wants to design an accelerated experiment because the materials do not display the same sulfur deposition behavior without it.

An accelerated biodeterioration chamber suitable for studying the durability of cementitious materials in sewer networks also needs the addition of sulfur-oxidizing bacteria to recreate the $\mathrm{pH}$ decrease observed in situ.

\section{Acknowledgements}

The authors gratefully thank Kerneos for providing cementitious materials and financial support. They also would like to acknowledge Veolia Eau, SIBA, and SABARC for allowing access to sewer networks and for monitoring environmental parameters.

\section{References}

De Belie, N., Monteny, J., Beeldens, A., Vincke, E., Van Gemert, D., Verstraete, W., 2004.

Experimental research and prediction of the effect of chemical and biogenic sulfuric acid on Research 34, 2223-2236. 
Delbes, C., Moletta, R., Godon, J.J., 2000. Monitoring of activity dynamics of an anaerobic digester bacterial community using 16S rRNA polymerase chain reaction - single-strand conformation polymorphism analysis. Environmental Microbiology 2, 506-515.

Delbes, C., Moletta, R., Godon, J.J., 2001. Bacterial and archaeal 16S rDNA and 16S rRNA dynamics during an acetate crisis in an anaerobic digestor ecosystem. FEMS Microbiology Ecology 35, 19-26.

Ehrich, S., Helard, L., Letourneaux, R., Willocq, J., Bock, E., 1999. Biogenic and Chemical Sulfuric Acid Corrosion of mortars. Journal of Materials in Civil Engineering 11, 340-344.

Espinosa, B., Letourneux, R., Marcdargent, S., 1996. Acid attack of hydraulic cement-bound materials: corrosion kinetics and neutralisation capacity. Proceedings of the $13^{\text {th }}$ international Corrosion Congress, Australasian Corrosion Association, Clayton, Vic., 4, 494-503.

Exley, C., Birchall, J.D., 1992. The cellular toxicity of aluminium. Journal of Theoretical Biology 159, 83-98.

Firer, D., Friedler, E., Lahav, O., 2008. Control of sulphide in sewer systems by dosage of iron salts: Comparison between theoretical and experimental results, and practical implications. Science of the Total Environment 392, 145-156.

Godon, J.J., Zumstein, E., Dabert, P., Habouzit, F., Moletta, R., 1997. Molecular microbial diversity of an anaerobic digestor as determined by small-subunit rDNA sequence analysis. Applied Environmental Microbiology 63, 2802-2813. 
373 Goyns, A., 2001. Calcium aluminate cement linings for cost-effective sewers. International Conference on CAC, Edinborough, 617-631.

375

Goyns, A., 2003. Virginia sewer rehabilitation, Progress report $n^{\circ} 1$ - PIPES, 21.

Hormann, K., Hofmann, F., Schmidt, M., 1997. Stability of concrete against biogenic sulfuric 379 acid corrosion, a new method for determination. Proceedings of the $10^{\text {th }}$ International Congress on the Chemistry of Cement, Gothenberg, 4vi038.

Islander, R.L., Devinny, J.S., Mansfeld, F., Postyn, A., Shih, H., 1991. Microbial ecology of crown corrosion in sewers. Journal of Environmental Engineering 117, 751-770.

Kaempfer, W., Berndt, M., 1999. Estimation of service life of concrete pipes in sewer networks. Durability of Building Materials and Components 8, 36-45.

Karlik, S.J., Eichhorn, G.L., Lewis, P.N., Crapper, D.R., 1980. Interaction of aluminium species with deoxyribonucleic acid. Biochemistry 19, 5991-5998.

Lamberet, S., Guinot, D., Lempereur, E., Talley, J., Alt, C., 2008. Field investigations of high performance calcium aluminate mortar for wastewater applications. In: Fentiman, C.H., Mangabhai, R.J., Scrivener, K.L., (Eds.), Calcium aluminate Cements - Proceedings of the centenary Conference, Avignon, 30 June - 2 July 2008, pp. 269-277. 
405

406

407

408

409

410

411

412

413

414

415

416

417

418

419

420

421

http://www.kerneosinc.com/pdfs/HRSD\%20SewperCoat\%20Reference\%20R\%2006-03.pdf

\section{LCA 2, Reference sheet 2}

$\underline{\text { http://www.kerneosinc.com/pdfs/ormondbeach.pdf }}$

Magniont, C., Coutand, M., Bertron, A., Cameleyre, X., Lafforgue, C., Beaufort, S., Escadeillas, G, 2011. A new test method to assess the bacterial deterioration of cementitious materials. Cement and Concrete Research 41, 429-438.

Milde, K., Sand, W., Wolff, W., Bock, E., 1983. Thiobacilli of the corroded concrete walls of the Hambourg sewer system. Journal of General Microbiology 129, 1327-1333.

Monteny, J., Vincke, E., Beeldens, A., De Belie, N., Taerwe, L., Van Gemert, D., Verstraete, W., 2000. Chemical, microbiological, and in situ test methods for biogenic sulphuric acid corrosion of concrete. Cement and Concrete Research 30, 623-634.

Munns, D.N., Keyser, H.N., 1981. Response of Rhizobium strains to acid and aluminium stress. Soil Biology and Biochemistry 13, 115-118.

Nielson, A.H., Vollertsen, J., Hvitved-Jacobson, T., 2005. Kinetics and stoichiometry of sulfide oxidation by sewer biofilms. Environmental Water Research 39, 4119-4125.

O’Connell, M., McNally, C., Richardson, M.G., 2010. Biochemical attack on concrete in wastewater applications: A state of the art review. Cement and Concrete Composites 32, 479485. 
423 Okabe, S., Odagiri, M., Ito, T., Satoh, H., 2007. Succession of Sulfur-Oxidizing Bacteria in 424 the Microbial Community on Corroding Concrete in Sewer Systems. Applied and 425 Environmental Microbiology 73, 971-980.

426

427 Olmstead, W.M., Hamlin H., 1900. Converting portions of the Los Angeles outfall sewer into 428 a septic tank. Engineering News 44, 317-138.

429

430

$431 \quad$ Nature 159, 439-440.

432

433 Roberts, D.J., Nica, D., Zuo, G., Davis, J.L., 2002. Quantifying microbially induced 434 deterioration of concrete: initial studies. International Biodeterioration and Biodegradation 49, 435 $227-234$.

436

437 Roy, D.M., Arjunan, P., Silsbee, M.R., 2001. Effect of silica fume, metakaolin, and low438 calcium fly ash on chemical resistance of concrete. Cement and Concrete Research 31, 1809$439 \quad 1813$.

440

441 Sand, W., Dumas, T., Marcdargent, S., 1992. Tests for biogenic sulfuric acid corrosion in a 442 simulation chamber confirm the on site performance of calcium aluminate based concretes in 443 sewage applications. International Symposium on Microbiologically Influenced Corrosion 444 (MIC) Testing - USA, Miami, Florida.

445 
Sand, W., Dumas, T., Marcdargent, S., 1994. Accelerated biogenic sulfuric-acid corrosion test

447 for evaluating the performance of calcium-aluminate based concrete in sewage applications 448 Microbiologically influenced corrosion testing, ASTM STP 1232, Jefrey R. Kearns and 449 Brenda J. Little, Eds., American Society for Testing and materials, Philadelphia, pp. 234-249.

450

451 Schmidt, M., Hormann, K., Hofmann, F.J., Wagner, E., 1997. Concrete with greater 452 resistance to acid and to corrosion by biogenous sulfuric acid. Concrete Precasting Plant and 453 Technology 4, 64-70.

454

Suzuki, I., 1999. Oxidation of inorganic sulfur compounds: Chemical and enzymatic reactions. Canadian Journal of Microbiology 45, 97-105.

457

458

459

correction of hydrogen sulfide corrosion in existing wastewater system. Office of wastewater

460 enforcement and compliance, Washington, DC, 20460.

461

462

Vincke, E., Verstichel, S., Monteny, J., Verstraete, W., 1999. A new test procedure for 463 biogenic sulfuric acid corrosion of concrete. Biodegradation 10, 421-428.

464

465

Wood, M., Coope, J.E., 1988. Acidity, aluminium and multiplication of Rhizobium trifolii: effects of initial inoculum density and growth phase. Soil Biology and Biochemistry 20, 83-

467 87.

\section{Captions}



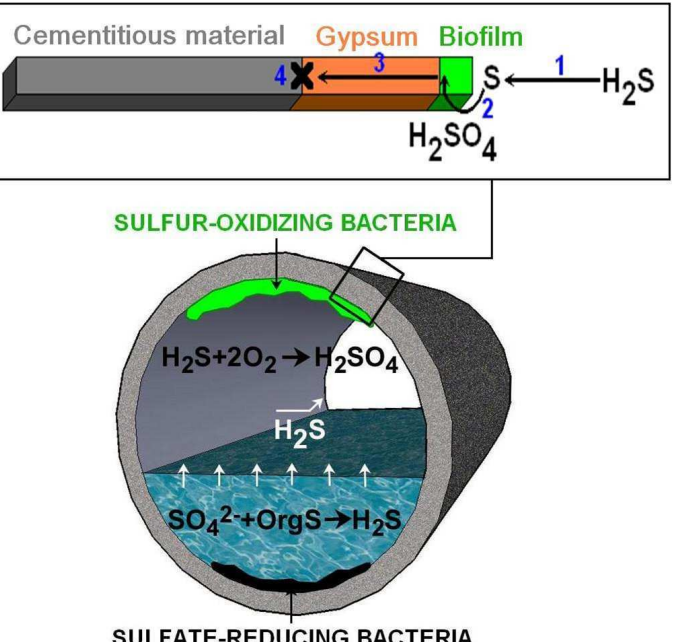

SULFATE-REDUCING BACTERIA

471 Fig. 1. Schematic representation of sulfur cycle in sewer network with the four steps involved

472 in the biodeterioration of cementitious materials.
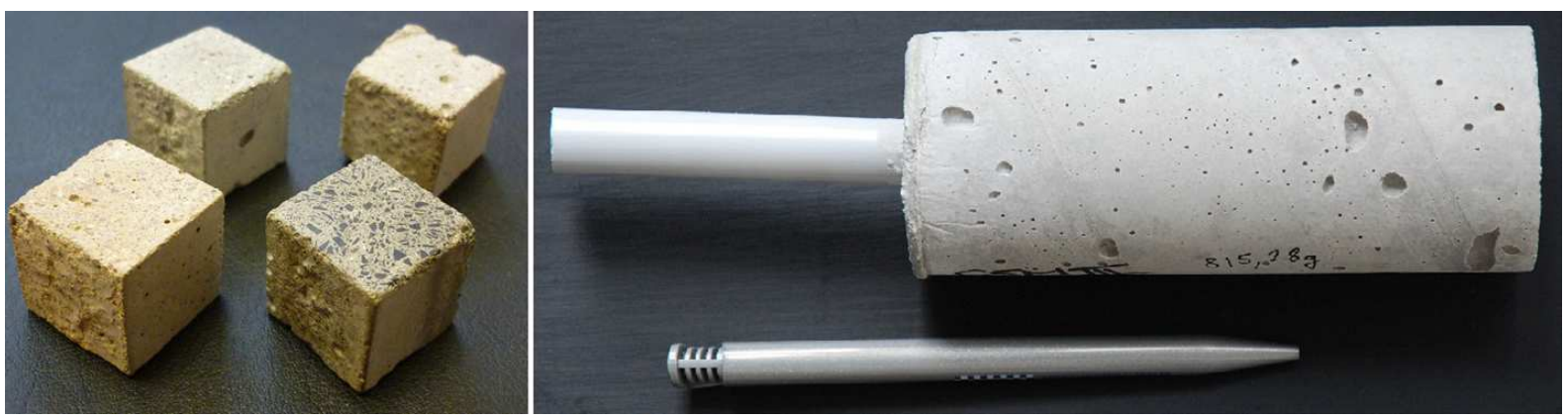

Fig. 2. Laboratory samples on the left and on-site samples on the right.
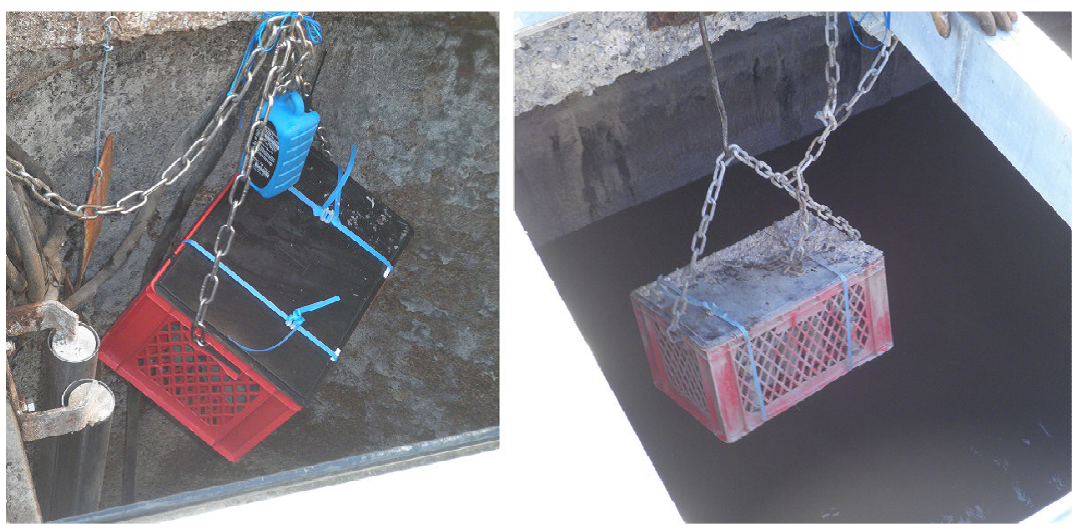

Fig. 3. Exposed boxes after four months in sewer networks. Site 1 is on the left, site 2 on the 479 right. 


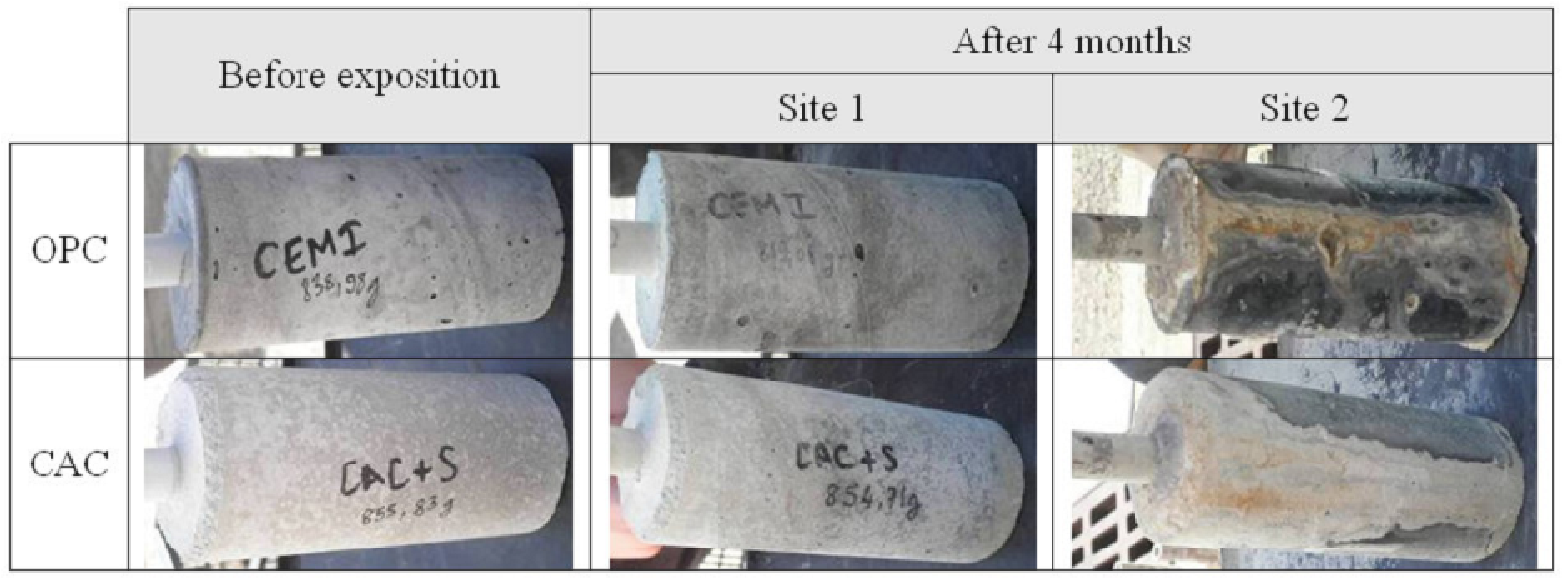

482 Fig. 4. Photos of the exposed samples after four months in the two sewer networks.

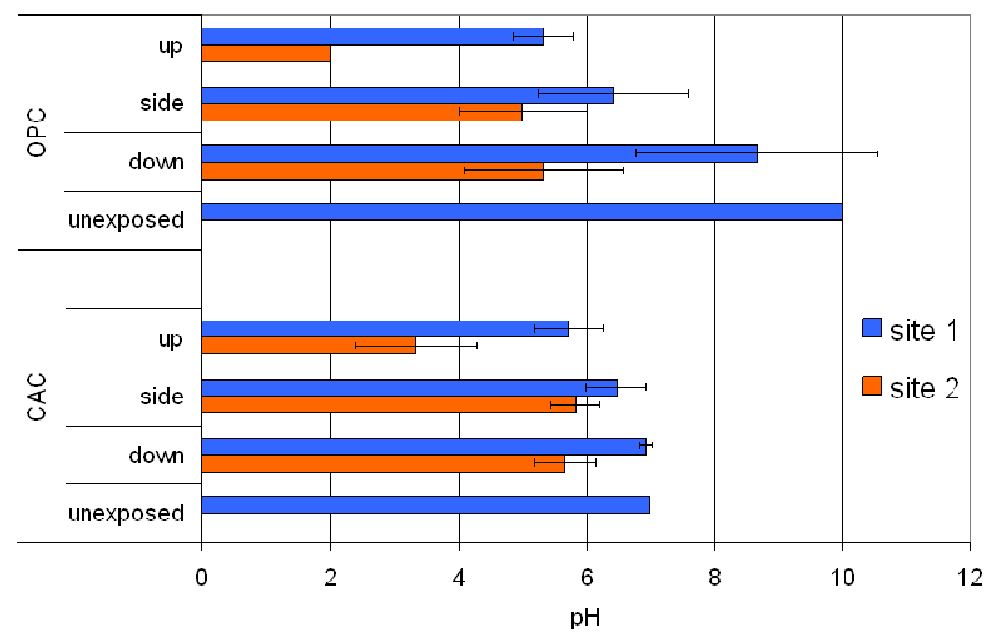

484

Fig. 5. Change of surface $\mathrm{pH}$ of samples after four months in a sewer network.

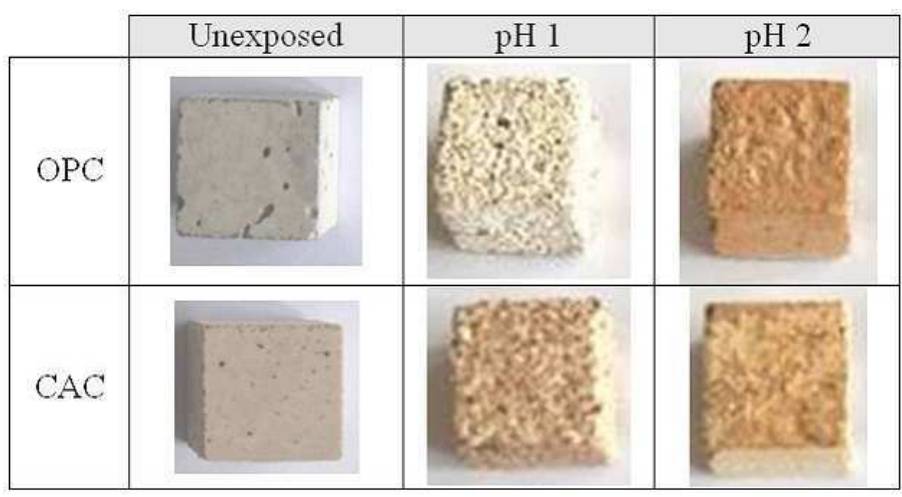

Fig. 6. Change of mortars immersed in sulfuric acid solution for a week. 


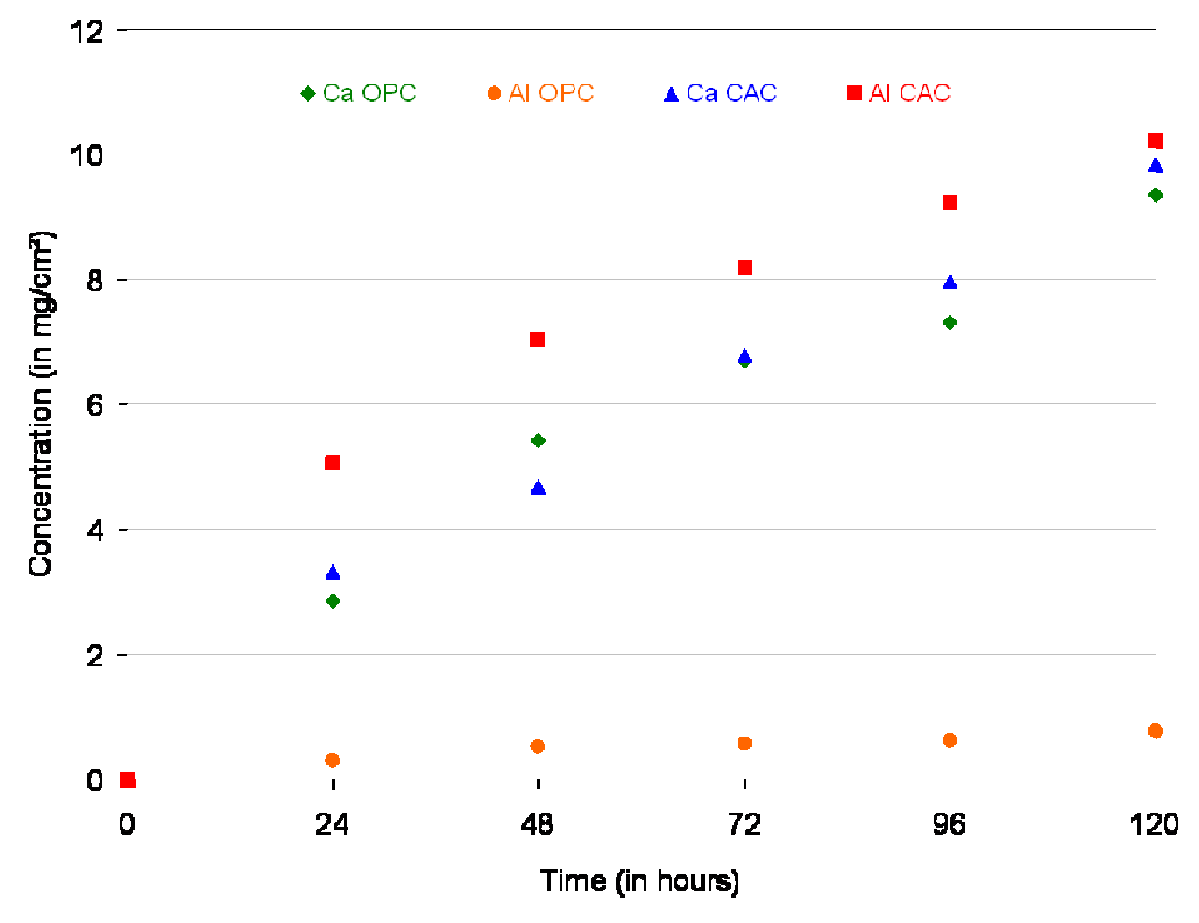

491 Fig. 7. Change of calcium and aluminum concentrations in acidic solution (pH 1) with OPC 492 and CAC materials.

493

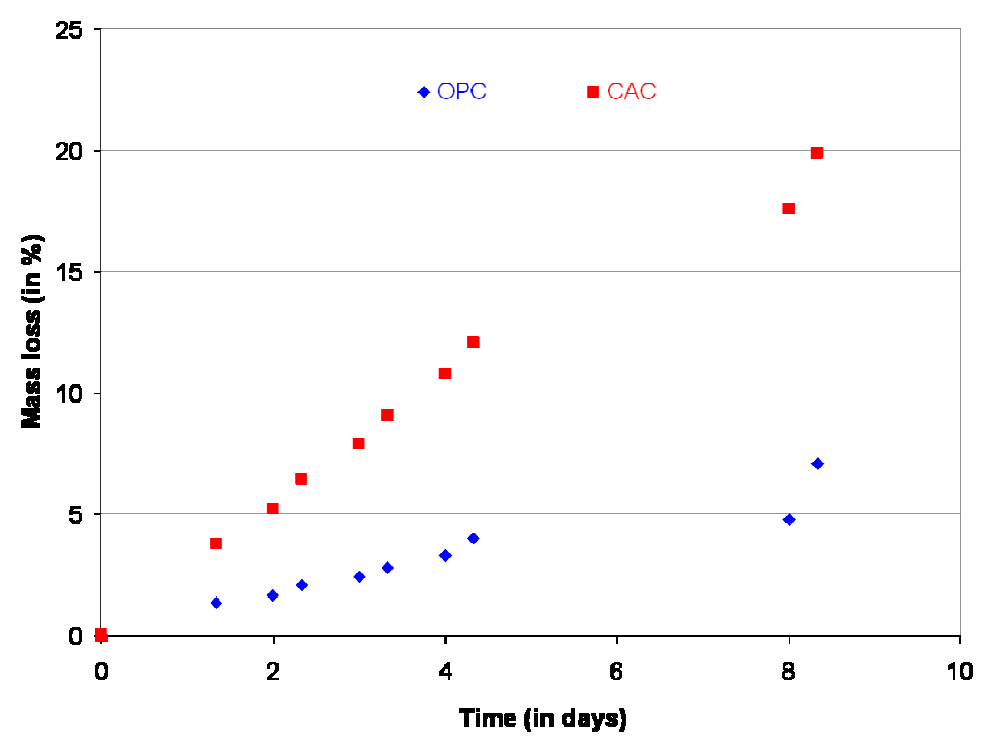

494

495 Fig. 8. Mass loss of samples over time during an immersion in sulfuric acid (pH 1). 


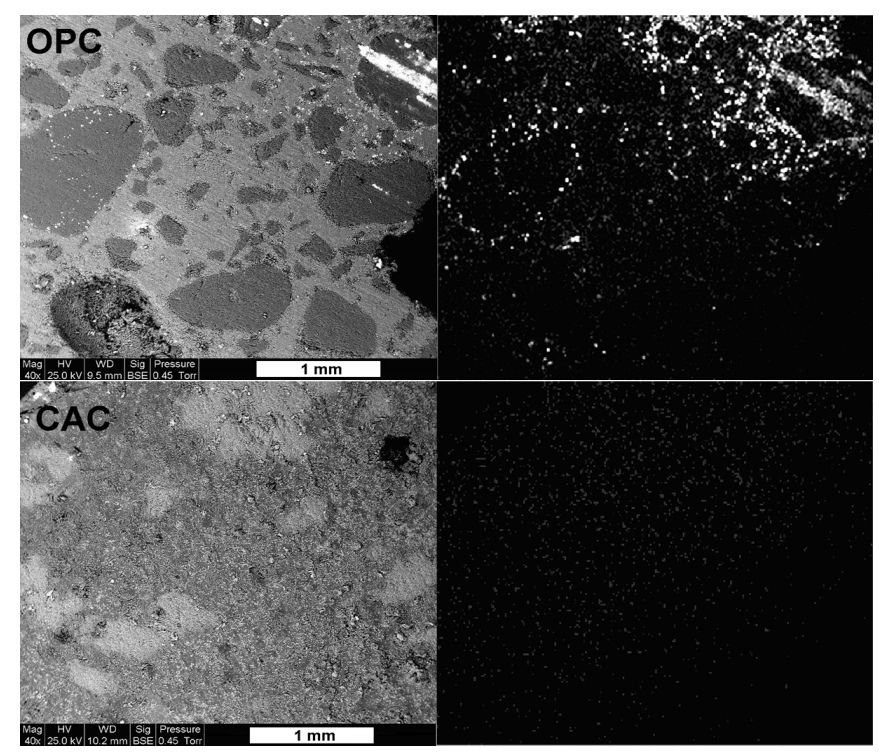

498 Fig. 9. SEM images of OPC and CAC surfaces exposed for 3 months to 20 ppm of $\mathrm{H}_{2} \mathrm{~S}$, on 499 the left. Sulfur mapping is on the right.

500

501

\section{Table 1}

503 Composition of the two cements.

\begin{tabular}{ccccccccccccc}
\cline { 2 - 12 } & $\mathrm{Al}_{2} \mathrm{O}_{3}$ & $\mathrm{CaO}$ & $\mathrm{SiO}_{2}$ & $\mathrm{Fe}_{2} \mathrm{O}_{3}$ & $\mathrm{MgO}$ & $\mathrm{TiO}_{2}$ & $\mathrm{SO}_{3}$ & $\mathrm{~K}_{2} \mathrm{O}$ & $\mathrm{Na}_{2} \mathrm{O}$ & $\mathrm{P}_{2} \mathrm{O}_{5}$ & LOI & IR \\
\hline $\mathrm{OPC}$ & 5.07 & 63.93 & 20.87 & 3.31 & 0.83 & 0.24 & 3.39 & 1.01 & 0.20 & 0.94 & 0.94 & 0.26 \\
\hline $\mathrm{CAC}$ & 51.87 & 37.06 & 5.31 & 2.25 & 0.54 & 2.19 & 0.15 & 0.31 & 0.05 & 0.19 & - & - \\
\hline
\end{tabular}

